\title{
Gallic acid has anticancer activity and enhances the anticancer effects of cisplatin in non-small cell lung cancer A549 cells via the JAK/STAT3 signaling pathway
}

\author{
TINGXIU ZHANG ${ }^{1 *}$, LIJIE MA $^{1 *}$, PENGFEI WU ${ }^{1}$, WEI LI ${ }^{2}$, TING LI $^{2}$, RUI GU ${ }^{2}$, XIAOPING DAN ${ }^{1}$, \\ ZHIWEI LI ${ }^{1}$, XIANMING FAN ${ }^{3}$ and ZHENLIANG XIAO ${ }^{1}$ \\ Departments of ${ }^{1}$ Respiratory Diseases and ${ }^{2}$ Central Laboratory, The General Hospital of Western Theater Command, \\ Chengdu, Sichuan 610083; ${ }^{3}$ Department of Respiratory Diseases, Southwest Medical University, \\ Luzhou, Sichuan 646000, P.R. China
}

Received November 30, 2017; Accepted October 24, 2018

DOI: 10.3892/or.2019.6976

\begin{abstract}
Gallic acid (3,4,5-trihydroxybenzoic acid; GA), a plant-derived natural phenolic compound, has been reported to prevent the development and progression of various types of cancers. However, there has been little elaboration of the anticancer effects and underlying mechanisms of GA alone and/or in combination with cisplatin in non-small cell lung cancer (NSCLC). The aim of the present study was to investigate the anticancer effects of GA on NSCLC A549 cells and its auxiliary effects on the anticancer activity of cisplatin. The results revealed that GA inhibited the proliferation and induced the apoptosis of NSCLC A549 cells in dose- and time-dependent manners, which was associated with upregulated B-cell lymphoma 2 (Bcl-2)-associated X protein (Bax) and downregulated Bcl-2. Notably, the results also indicated that GA enhanced the anticancer effects of cisplatin in the inhibition of cancer cell proliferation and the induction of cell apoptosis following elevated Bax expression and suppressed Bcl-2 expression. Furthermore, the results of the present study also demonstrated that GA exerted independent anticancer effects on NSCLC A549 cells, and facilitated the anticancer effects of cisplatin by modulating the JAK/STAT3 signaling pathway and downstream apoptotic molecules. These results may serve as a rationale for further basic studies and preclinical
\end{abstract}

Correspondence to: Professor Zhenliang Xiao, Department of Respiratory Diseases, The General Hospital of Western Theater Command, 270 Tianhui Road, Rongdu Avenue, Jinniu, Chengdu, Sichuan 610083, P.R. China

E-mail: xiaozhenliang2001@aliyun.com

${ }^{*}$ Contributed equally

Key words: gallic acid, cisplatin, non-small cell lung cancer, apoptosis, Janus kinase 1/signal transducer and activator of transcription 3 pathway investigations on the anticancer effects of GA and its auxiliary effects on cisplatin function in human NSCLC.

\section{Introduction}

Lung cancer is one of the common malignant tumors, accounting for $12 \%$ of all primarily diagnosed cancer cases, and is established as the main cause of cancer-associated mortality worldwide $(1,2)$. Non-small cell lung cancer (NSCLC) is a prominent type of lung cancer, comprising $85 \%$ of all lung cancer cases worldwide $(3,4)$. Although therapeutic strategies including targeted therapy, immunotherapy and traditional chemotherapy have achieved considerable success in improving the prognosis of patients with NSCLC over the past decades, the majority of patients still suffer from local aggravation and/or systemic metastasis, and do not survive $>5$ years following diagnosis (5). Therefore, it is essential to identify novel therapeutics that are capable of significantly elevating the 5-year survival rate while causing little sideeffects in NSCLC patients.

With advances in research on Traditional Chinese Medicine (TCM), many agents extracted from natural plants have attracted increasing levels of public attention in recent years for their apparent favorable pharmacokinetic characteristics and mild side-effects. Gallic acid (3,4,5-trihydroxybenzoic acid; GA), a natural phenolic compound, is one such plant extract that is present in abundance in tea, grapes, gall-nuts and red wine $(6,7)$. It has been reported to possess various pharmacological and biological properties, including antibacterial, antiviral and antitumor activities. Recently, there has been an increased research focus on the antitumor capacity of GA in different cancer cell lines, including oral, lung, pancreatic and cervical cancer cells $(8,9)$, and it is thought that regulation of apoptosis may be critically involved in the antitumor effects of GA. However, understanding of how GA induces cell apoptosis is still limited.

Signal transducer and activator of transcription 3 (STAT3) is a member of the STAT transcription factor family, which has been associated with various biological processes, including cell growth, survival and metastasis (10). STAT3 mainly exists 
in the cytoplasm, where it can be phosphorylated at Tyr705 via Janus kinase (JAK)-mediated tyrosine phosphorylation when stimulated by cytokines. The phosphorylated STAT3 translocates into the nucleus, combines with DNA sites, and regulates various cellular processes, including cell apoptosis and proliferation $(11,12)$. Persistent activation of STAT3 has been observed in $>70 \%$ of solid and hematological tumors, which may be one of the most notable differences between normal and malignant cells (13). Additionally, a previous study reported that aberrant activation of STAT3 is present in the majority of NSCLC cell lines and $~ 55 \%$ of NSCLC patients (14), indicating a potential association between STAT3 activation and NSCLC development. However, further investigation is required in order to fully illustrate how STAT3 expression is associated with NSCLC development.

Taking these findings into consideration, the present study hypothesized and investigated whether GA exerts its anticancer effects on NSCLC A549 cells by modulating the phosphorylation of JAK1 and STAT3, and the expression of downstream apoptotic molecules, including B-cell lymphoma 2 (Bcl-2) and Bcl-2-associated X protein (Bax). Notably, it was also evaluated and confirmed that GA facilitates the anticancer effects of cisplatin in A549 cells by regulating the JAK/STAT3 signaling pathway.

\section{Materials and methods}

Materials. The human NSCLC cell line A549 was purchased from Shanghai Bioleaf Biotech Co., Ltd. (Shanghai, China). GA of purity $>98 \%$ was purchased from Shanghai Source Biological Technology Co., Ltd. (Shanghai, China). Primary antibodies against JAK1, STAT3, p-STAT3 ${ }^{\text {Tyr705 }}$, Bax, Bcl-2, $\beta$-actin and GAPDH, and the secondary antibody anti-rabbit horseradish peroxidase (HRP)-immunoglobulin (Ig) G were acquired from Wuhan Boster Biological Technology Co., Ltd. (Wuhan, China). The antibody against phosphorylated (p)-JAK $1^{\mathrm{Y} 1022}$ was acquired from Elabscience Biotechnology Co., Ltd (Chengdu, China). An MTT Cell Proliferation and Cytotoxicity Assay kit, Annexin V-fluorescein isothiocyanate (FITC) Apoptosis Detection kit, RPMI-1640 medium, penicillin-streptomycin liquid, trypsin-EDTA solution $(0.25 \%)$ with phenol red and crystal violet were obtained from Beijing Solarbio Science \& Technology Co., Ltd. (Beijing, China). Fetal bovine serum (FBS) was purchased from Gibco (Thermo Fisher Scientific, Inc., Waltham, MA, USA).

Cell culture. The A549 cell line was maintained in RPMI-1640 medium containing $10 \% \mathrm{FBS}, 100 \mathrm{U} / \mathrm{ml}$ penicillin and $0.1 \mathrm{mg} / \mathrm{ml}$ streptomycin, in a humidified incubator at $37^{\circ} \mathrm{C}$ with $5 \% \mathrm{CO}_{2}$. Cells at logarithmic phase were used in the following experiments.

Cell viability assay. An MTT assay was performed to evaluate the effects of cisplatin (Jiangsu Haosen Pharmaceutical Group, Co., Ltd., Jiangsu, China), GA and their combination on cell viability. A549 cells were seeded in 96-well plates at a density of $2 \times 10^{4}$ cells/well. The cells were treated at $37^{\circ} \mathrm{C}$ with GA [varied dose $(0-52 \mu \mathrm{g} / \mathrm{ml})$ of GA for $24 \mathrm{~h}$, or 12,20 and $28 \mu \mathrm{g} / \mathrm{ml} \mathrm{GA}$ for 6,24 and $48 \mathrm{~h}$ ], cisplatin [varied dose
(0-32 $\mu \mathrm{g} / \mathrm{ml})$ of cisplatin for $24 \mathrm{~h}$ ] or the two compounds combined $(2.5 \mu \mathrm{g} / \mathrm{ml}$ of cisplatin, $28 \mu \mathrm{g} / \mathrm{ml}$ of GA or the two combined for $6,12,24$ and $48 \mathrm{~h}$ ) when the cells reached $80 \%$ confluency. The medium was removed following 6-24 h of incubation, $10 \mu \mathrm{l}$ MTT $(5 \mathrm{mg} / \mathrm{ml})$ was added to each well, and the cells were incubated for a further $4 \mathrm{~h}$. The medium of each well was then removed and replaced by $110 \mu$ dimethylsulfoxide at the end of the incubation. Finally, the absorbance of each well at $492 \mathrm{~nm}$ was measured with a spectrophotometer (Thermo Fisher Scientific, Inc.) and cell viability was evaluated by analyzing the absorbance of each group.

Cell apoptosis assay. A549 cells were seeded into 6-well plates at a density of $2 \times 10^{5} /$ well and divided into the following groups: i) Control group (Control), treated with normal medium; ii) GA group (GA), treated with $12-28 \mu \mathrm{g} / \mathrm{ml} \mathrm{GA}$; iii) cisplatin group (Pt 2.5), treated with $2.5 \mu \mathrm{g} / \mathrm{ml}$ cisplatin; and iv) GA + cisplatin group (Pt 2.5 + GA28), treated with $2.5 \mu \mathrm{g} / \mathrm{ml}$ cisplatin $+28 \mu \mathrm{g} / \mathrm{ml}$ GA. Cells from each group were treated at $37^{\circ} \mathrm{C}$ for 6 and $24 \mathrm{~h}$, respectively. Cells were collected via centrifuged at $300 \mathrm{x} \mathrm{g}$ at $37^{\circ} \mathrm{C}$ for $5 \mathrm{~min}$ and washed 3 times with cold phosphate-buffered saline (PBS) and then suspended in binding buffer. The cells were then stained with Annexin V-FITC according to the instructions of the Apoptosis Detection kit (Beijing Solarbio Science \& Technology Co., Ltd.). Finally, a flow cytometer (Sysmex Partec Gmbh, Görlitz, Germany) was used to determine the percentage of apoptotic cells in each group.

Crystal violet staining assay. A549 cells were cultured in 96-well plates and treated as aforementioned for $24 \mathrm{~h}$ when cells reached a confluence of $70-80 \%$. The medium was removed at the end of the treatment period and cells were washed with cold PBS and fixed in $4 \%$ paraformaldehyde for $30 \mathrm{~min}$ at room temperature. The cells were then washed again with cold PBS and stained at room temperature with crystal violet for a further 2 min. Finally, the cells were washed with PBS and dried naturally prior to being observed under an inverted phase contrast microscope (Olympus Corporation, Tokyo, Japan).

Western blot analysis. Cells were treated with GA, cisplatin or the two compounds combined for $24 \mathrm{~h}$, as aforementioned. The total proteins of cells in each group were then extracted using a Total Protein Extraction kit (Nanjing KeyGen Biotech, Co., Ltd. Nanjing, China) according to the manufacturer's instructions. The concentration of proteins was quantified with a BCA Protein Assay kit (Beijing Solarbio Science \& Technology Co., Ltd.). The proteins were then mixed with sample buffer, separated on $10 \%$ SDS-polyacrylamide gels and transferred onto PVDF membranes. The membranes were blocked at room temperature for $2 \mathrm{~h}$ with $5 \%$ dried skimmed milk or $5 \%$ bovine serum albumin (Beijing Solarbio Science \& Technology Co., Ltd.) dissolved in TBST (containing $0.02 \%$ Tween-20) and incubated with the primary antibodies at $4^{\circ} \mathrm{C}$ overnight: JAK1 (cat. no. BA1808), p-JAK1 (cat. no. ENP0154), STAT3 (cat. no. BA0621), p-STAT3 (cat. no. P00007), Bax (cat. no. BA0315), Bcl-2 (cat. no. BA0412), $\beta$-actin (cat.no. BM0627) or GAPDH (cat.no. BA2913) at the dilution of 1:1,000-1:5,000. Subsequently, the membranes were washed 3 times with TBST, incubated with anti-rabbit IgG secondary 

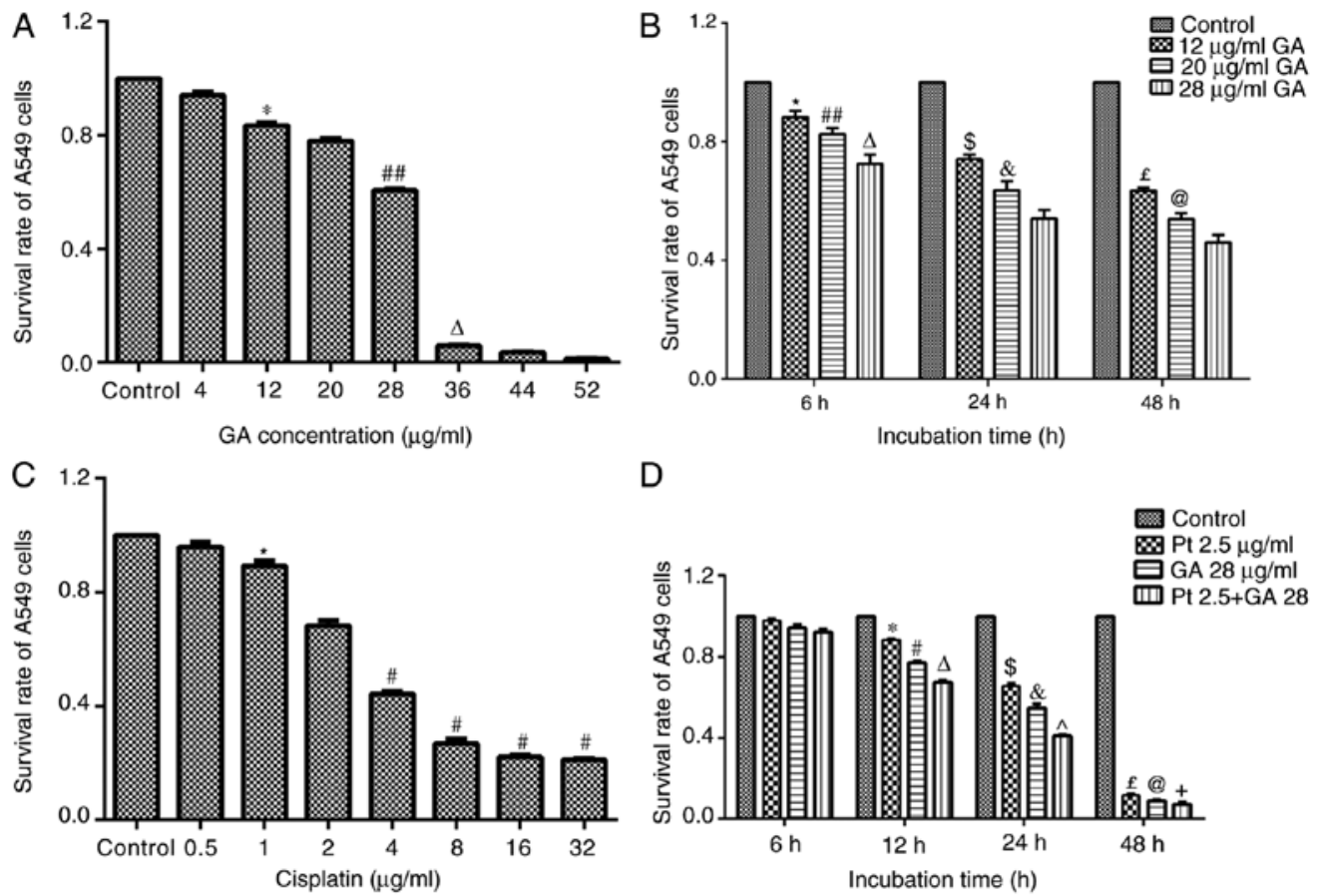

D

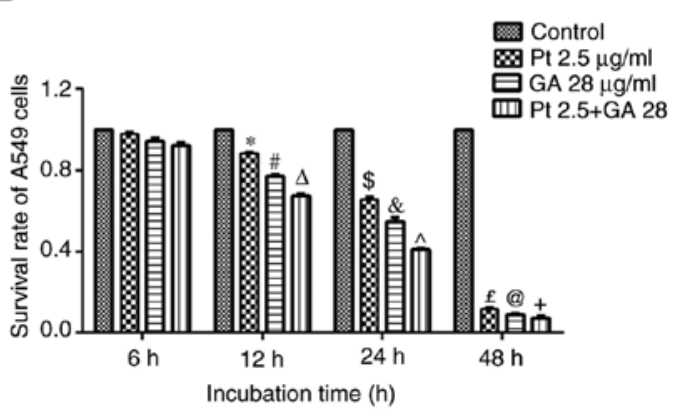

Figure 1. Effects of GA, cisplatin and their combination on A549 cell proliferation as detected by MTT assay. The results were expressed as the mean \pm standard deviation of separate experiments. (A) GA at $12 \mu \mathrm{g} / \mathrm{ml}$ significantly inhibited cell viability compared with control treatment. GA at concentrations of $28 \mu \mathrm{g} / \mathrm{ml}$ exhibited a greater inhibitory effect on cell viability compared with $12 \mu \mathrm{g} / \mathrm{ml} \mathrm{GA}$, and much greater inhibition was observed when cells were treated with $36-52 \mu \mathrm{g} / \mathrm{ml} \mathrm{GA} .{ }^{~} \mathrm{P}<0.05 \mathrm{vs}$. Control; ${ }^{\# \#} \mathrm{P}<0.01 \mathrm{vs.} 12 \mu \mathrm{g} / \mathrm{ml} ;{ }^{\Delta} \mathrm{P}<0.05 \mathrm{vs} .52 \mu \mathrm{g} / \mathrm{ml}$. (B) The viability of cells was significantly inhibited by GA in a dose- and time-dependent manner. ${ }^{\prime \prime} \mathrm{P}<0.05$ vs. Control; ${ }^{\# \#} \mathrm{P}<0.01$ vs. $12 \mu \mathrm{g} / \mathrm{ml} ;{ }^{\Delta} \mathrm{P}<0.05$ vs. $20 \mu \mathrm{g} / \mathrm{ml} ;{ }^{\$} \mathrm{P}<0.05$ vs. $12 \mu \mathrm{g} / \mathrm{ml}$ at $6 \mathrm{~h}$; ${ }^{\mathrm{E}} \mathrm{P}<0.05 \mathrm{vs}$. $12 \mu \mathrm{g} / \mathrm{ml}$ at $24 \mathrm{~h} ;{ }^{\&} \mathrm{P}<0.05$ vs. $20 \mu \mathrm{g} / \mathrm{ml}$ at $6 \mathrm{~h} ;{ }^{\circledR} \mathrm{P}<0.05$ vs. $20 \mu \mathrm{g} / \mathrm{ml}$ at $24 \mathrm{~h}$. (C) Treatment with $1 \mu \mathrm{g} / \mathrm{ml}$ cisplatin for $24 \mathrm{~h}$ reduced the viability of cells. A dose of $4 \mu \mathrm{g} / \mathrm{ml}$ cisplatin exhibited a greater inhibitory effect on the viability of A549 cells when compared with that of $1 \mu \mathrm{g} / \mathrm{ml}$, and significant inhibitory effects were observed when cells were treated with 8,16 or $32 \mu \mathrm{g} / \mathrm{ml}$ cisplatin compared with that of $1 \mu \mathrm{g} / \mathrm{ml}$. ${ }^{*} \mathrm{P}<0.05 \mathrm{vs}$. Control; " ${ }^{\text {P }}<0.05 \mathrm{vs}$. $1 \mu \mathrm{g} / \mathrm{ml}$. (D) GA, cisplatin or a combination of the two agents decreased cell viability in a time-dependent manner. Cotreatment with GA markedly enhanced the effects of cisplatin at different time points. ${ }^{\mathrm{P}} \mathrm{P}<0.05 \mathrm{vs}$. Pt $2.5 \mu \mathrm{g} / \mathrm{ml}$ at $6 \mathrm{~h} ;{ }^{\prime} \mathrm{P}<0.05 \mathrm{vs}$. GA $28 \mu \mathrm{g} / \mathrm{ml}$ at $6 \mathrm{~h} ;{ }^{\wedge} \mathrm{P}<0.05$ vs. Pt $2.5+\mathrm{GA} 28$ at $6 \mathrm{~h} ;{ }^{\$} \mathrm{P}<0.05 \mathrm{vs}$. Pt $2.5 \mu \mathrm{g} / \mathrm{ml}$ at $12 \mathrm{~h} ;{ }^{\circ} \mathrm{P}<0.05$ vs. GA $28 \mu \mathrm{g} / \mathrm{ml}$ at $12 \mathrm{~h} ;{ }^{\wedge} \mathrm{P}<0.05$ vs. Pt $2.5+\mathrm{GA} 28$ at $12 \mathrm{~h} ;{ }^{\mathrm{e}} \mathrm{P}<0.05$ vs. Pt $2.5 \mu \mathrm{g} / \mathrm{ml}$ at $24 \mathrm{~h} ;{ }^{\circledR} \mathrm{P}<0.05$ vs. GA $28 \mu \mathrm{g} / \mathrm{ml}$ at $24 \mathrm{~h} ;{ }^{+} \mathrm{P}<0.05 \mathrm{vs}$. Pt $2.5+\mathrm{GA} 28$ at 24 h. GA, Gallic acid; Pt, cisplatin.

antibody conjugated with $\operatorname{HRP}(1: 5,000$; cat. no. BA1056) for $1 \mathrm{~h}$ at room temperature and then washed 3 times with TBST. Finally, the signals indicating expression levels of target proteins were detected using Chemiluminescent HRP Substrate (EMD Millipore, Billerica, MA, USA) and ImageJ 1.8.0 software (National Institutes of Health, Bethesda, MD, USA).

Immunofluorescent staining assay. Cells were cultured in 24-well plates on sterile glass coverslips placed in each well and treated as aforementioned. The cells were then fixed at $4^{\circ} \mathrm{C}$ with $4 \%$ paraformaldehyde for $30 \mathrm{~min}$ and washed twice with PBS. Triton X-100 solution (0.1\%) was used to disrupt the cytomembrane, then cells were blocked in $10 \%$ normal goat serum (Beijing Solarbio Science \& Technology Co., Ltd.) at room temperature for $1 \mathrm{~h}$, and incubated with p-STAT3 (dilution, 1:1,000; cat. no. P00007) at $4^{\circ} \mathrm{C}$ overnight. Subsequently, the cells were incubated with biotin-labeled secondary antibody (dilution, 1:64; cat. no. BA1090; Wuhan Boster Biological Technology Co., Ltd.) for $40 \mathrm{~min}$ at $37^{\circ} \mathrm{C}$. Finally, nuclei were stained with DAPI at room temperature for $1 \mathrm{~min}$ and the slides were observed with a fluorescent microscope (Olympus Corporation; magnification, x200).

Reverse transcription-quantitative polymerase chain reaction $(R T-q P C R)$. The total RNA of cells treated with the various doses of GA (12-28 $\mu \mathrm{g} / \mathrm{ml})$ were isolated with TRIzol reagent
(Thermo Fisher Scientific, Inc.), and then a NanoDrop ND-1000 spectrophotometer was used to measure the concentration and purity of RNA samples. Subsequently, $2 \mu \mathrm{g}$ total RNA was reverse transcribed $\left(37^{\circ} \mathrm{C}\right.$ for $15 \mathrm{~min}$ and $85^{\circ} \mathrm{C}$ for $\left.5 \mathrm{sec}\right)$ into cDNA using a SuperScript III First-Strand Synthesis System for RT-PCR (Invitrogen; Thermo Fisher Scientific, Inc.). PCR was performed with a $25 \mu 1$ reaction mixture including $2 \mu 1$ cDNA. RT-qPCR was performed using SYBR Premix Ex Taq II supplied (Takara Bio, Inc., Otsu, Japan). Primers used for the RT-qPCR were as follows: GAPDH forward, 5'-ACTT TGGTATCGTGGAAGGACTCAT-3' and reverse, 5'-GTTTTT CTAGACGGCAGGTCAGG-3'; Bax forward, 5'-TTTTGC TTCAGGGTTTCATCCA-3' and reverse, 5'-TGCCACTCG GAAAAAGACCTC-3'; Bcl-2 forward, 5'-ATCGCCTGTGGA TGACTGA-3' and reverse, 5'-GAGACAGCCAGGAGAAAT CAAAC-3'; STAT3 forward, 5'-ACCAAGCGAGGACTGAGC ATC-3' and reverse, 5'-CAGCCAGACCCAGAAGGAGAA-3'; and JAK1 forward, 5'-ACCAGGATGCGGATAAATAATG-3' and reverse, 5'-GTTTCCAAGGTAGCCAAGTATTT-3'. qPCR amplification was performed in two steps: An initial step at $95^{\circ} \mathrm{C}$ for $30 \mathrm{sec}$, and then 40 cycles of $95^{\circ} \mathrm{C}$ for $5 \mathrm{sec}$ and $60^{\circ} \mathrm{C}$ for $30 \mathrm{sec}$. Finally, the expression levels of target mRNAs were calculated according to $2^{-\Delta \Delta \mathrm{Cq}}$ method (15).

Statistical analysis. All quantitative data were presented as the mean \pm standard deviation, and statistical analysis was 


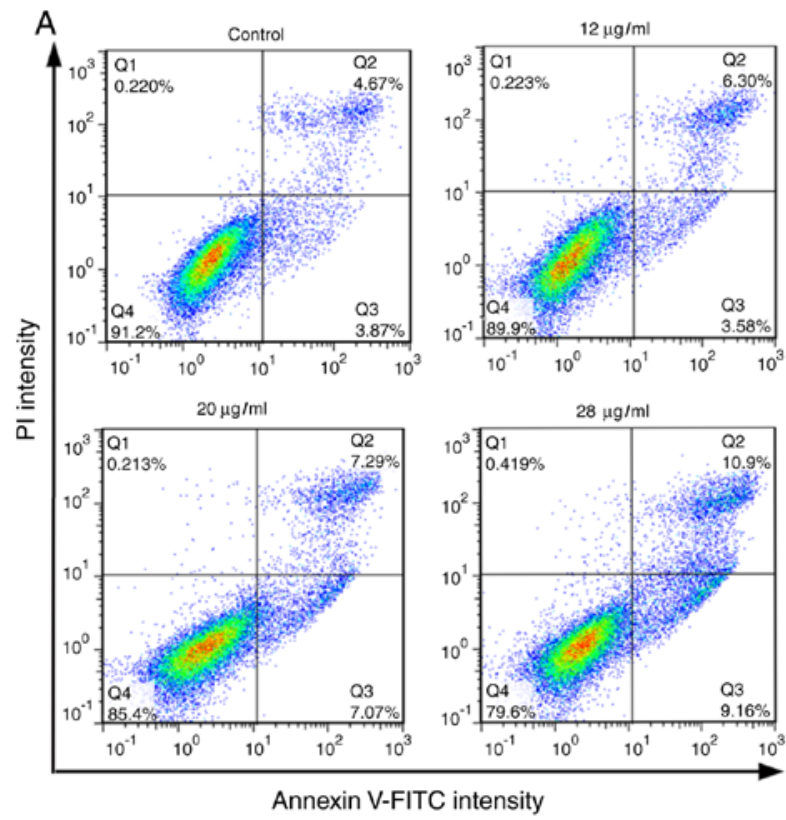

B

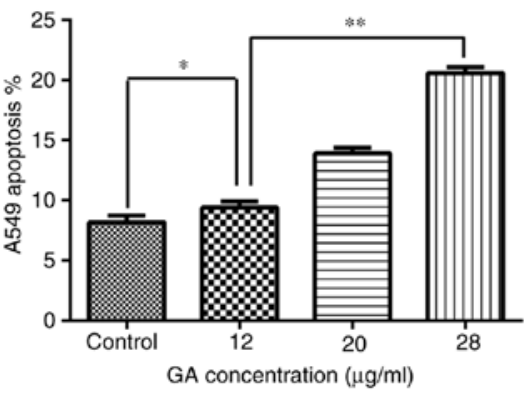

Figure 2. GA induces apoptosis in A549 cells. The results were expressed as the mean \pm standard deviation of separate experiments. (A) Representative flow cytometry histograms of cell apoptosis analysis. (B) Results of cell apoptosis analysis. GA at $12 \mu \mathrm{g} / \mathrm{ml}$ increased the percentage of early and total apoptotic cells when compared with control treatment following $24 \mathrm{~h}$ of incubation. GA at $28 \mu \mathrm{g} / \mathrm{ml}$ induced a more significant increase in apoptosis in A549 cells when compared with $12 \mu \mathrm{g} / \mathrm{ml} .{ }^{*} \mathrm{P}<0.05$ and ${ }^{* *} \mathrm{P}<0.01$, as indicated. GA, Gallic acid; PI, propidium iodide; FITC, fluorescein isothiocyanate.

performed with SPSS 19.0 (IBM Corp., Armonk, NY, USA). One-way analysis of variance followed by the Least Significant Difference post hoc test was applied to analyze the differences among groups. $\mathrm{P}<0.05$ was considered to indicate a statistically significant difference.

\section{Results}

GA decreases the viability of A549 cells. A549 cells were treated with GA $(0-52 \mu \mathrm{g} / \mathrm{ml})$ for $24 \mathrm{~h}$ and cell viability was detected by MTT assay. It was observed that GA decreased cell viability in a dose-dependent manner (Fig. 1A). Specifically, $12 \mu \mathrm{g} / \mathrm{ml} \mathrm{GA}$ significantly decreased cell viability when compared with that of control cells $(\mathrm{P}<0.05)$; the greater concentration of $28 \mu \mathrm{g} / \mathrm{ml}$ in turn caused a greater inhibition of cell viability when compared with $12 \mu \mathrm{g} / \mathrm{ml}$ GA $(\mathrm{P}<0.05)$; cell viability was $<10 \%$ when A549 cells were treated with GA at a dose of $36 \mu \mathrm{g} / \mathrm{ml} \mathrm{GA}$; and cell viability was further inhibited when cells were treated with $52 \mu \mathrm{g} / \mathrm{ml} \mathrm{GA}$. Based on these findings, $12-28 \mu \mathrm{g} / \mathrm{ml} \mathrm{GA}$ was adopted for subsequent studies. It was further identified that the viability of cells was significantly inhibited by GA in dose- and time-dependent manners (Fig. 1B).

GA induces the apoptosis of A549 cells. To investigate the influence of GA on apoptosis, A549 cells were treated with 12,20 or $28 \mu \mathrm{g} / \mathrm{ml} \mathrm{GA}$ for $24 \mathrm{~h}$ and the number of apoptotic cells was calculated by flow cytometry. The results demonstrated that $12 \mu \mathrm{g} / \mathrm{ml} \mathrm{GA}$ significantly increased the percentage of early and total apoptotic cells when compared with the control group following $24 \mathrm{~h}$ of incubation $(\mathrm{P}<0.05)$. Notably, treatment with $28 \mu \mathrm{g} / \mathrm{ml}$ GA led to a more significant increase in apoptosis in A549 cells compared with $12 \mu \mathrm{g} / \mathrm{ml}$ GA $(\mathrm{P}<0.01)$, which indicated that GA induced A549 cell apoptosis in a dose-dependent manner (Fig. 2).
GA interferes with the expression of Baxand Bcl-2 in A549 cells. To further ascertain the antitumor effects of GA in A549 cells, the expression of Bax and Bcl-2 in cells from each group was measured by RT-qPCR and western blot analysis. The results revealed that GA upregulated Bax and downregulated Bcl-2 at the gene and protein levels (Fig. 3). Specifically, $12 \mu \mathrm{g} / \mathrm{ml} \mathrm{GA}$ enhanced Bax protein (Fig. 3A) and gene (Fig. 3C) expression relative to the levels in control cells $(\mathrm{P}<0.05)$; and increased concentrations of GA (20 and $28 \mu \mathrm{g} / \mathrm{ml})$ further enhanced Bax expression at the gene and protein levels when compared with $12 \mu \mathrm{g} / \mathrm{ml} \mathrm{GA}(\mathrm{P}<0.05)$. By contrast, $12 \mu \mathrm{g} / \mathrm{ml} \mathrm{GA}$ decreased the expression of Bcl-2 protein (Fig. 3B) and mRNA (Fig. 3D) compared with control treatment $(\mathrm{P}<0.05)$, and further inhibition of Bcl-2 expression was observed when A549 cells were treated with 20 or $28 \mu \mathrm{g} / \mathrm{ml} \mathrm{GA}$ ( $\mathrm{P}<0.05$ vs. $12 \mu \mathrm{g} / \mathrm{ml} \mathrm{GA}$; Fig. 3B and D).

GA inhibits the JAK/STAT3 signaling pathway in A549 cells. It is widely accepted that the JAK/STAT3 signaling pathway is involved in various biological processes, including cell proliferation, survival and development (14). To determine whether the JAK/STAT3 signaling pathway was associated with the anticancer effects of GA, the expression of JAK1 and STAT3 was examined in A549 cells from each group by RT-qPCR and western blotting. The results revealed that $12 \mu \mathrm{g} / \mathrm{ml} \mathrm{GA}$ reduced the levels of p-JAK $1^{\mathrm{Y} 1022}$ and p-STAT3 ${ }^{\mathrm{Ty} r 705}$ when compared with control treatment $(\mathrm{P}<0.05)$; greater reductions in $\mathrm{p}-\mathrm{JAK} 1^{\mathrm{Y} 1022}$ and p-STAT3 ${ }^{\text {Tyr705 }}$ expression were observed when cells were treated with 20 or $28 \mu \mathrm{g} / \mathrm{ml} \mathrm{GA}$ (P<0.05 vs. $12 \mu \mathrm{g} / \mathrm{ml}$; Fig. 4A and B), which indicated that GA reduced p-JAK1 $1^{\mathrm{Y} 1022}$ and p-STAT3 ${ }^{\text {Tyr705 }}$ in a dose-dependent manner. By contrast, varied doses of GA exerted little influence on the gene expression of JAK1 and STAT3 (Fig. 4C and D), which indicated that GA interfered with the phosphorylation of JAK1 and STAT3, rather than expression. 
A
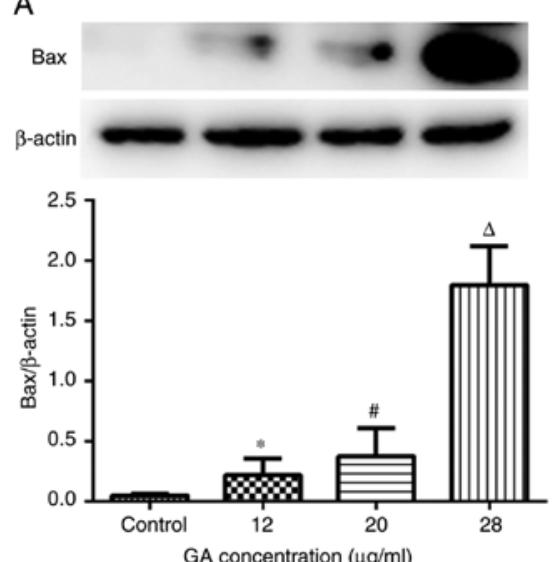

C

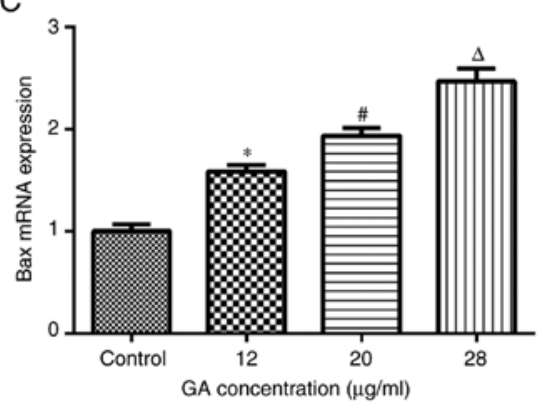

B
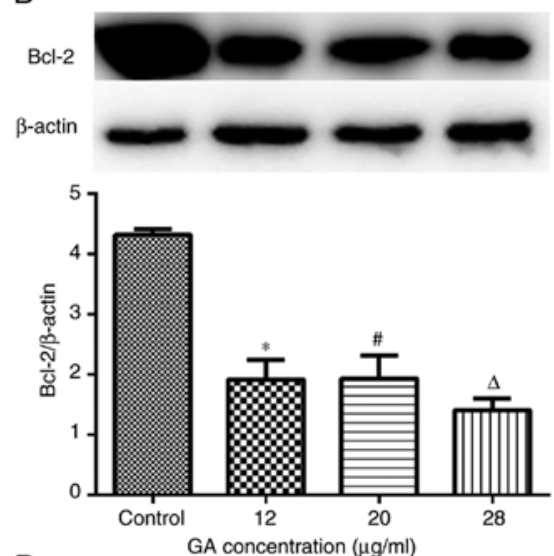

D

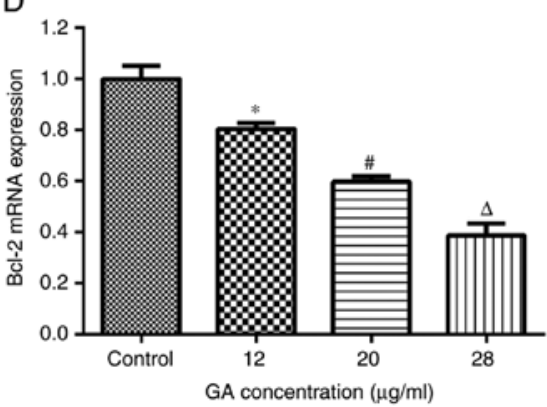

Figure 3. Expression of (A and C) Bax and (B and D) Bcl-2 was measured by western blot analysis and reverse transcription-quantitative polymerase chain reaction. GA at $12 \mu \mathrm{g} / \mathrm{ml}$ enhanced Bax expression at the (A) protein and (C) gene levels compared with control treatment. GA at 20 and $28 \mu \mathrm{g} / \mathrm{ml}$ exaggerated the enhancement of Bax expression at the gene and protein levels. By contrast, $12 \mu \mathrm{g} / \mathrm{ml} \mathrm{GA}$ decreased Bcl-2 expression at the (B) protein and (D) gene levels compared with control treatment. GA at 20 and $28 \mu \mathrm{g} / \mathrm{ml}$ enhanced the reduction of Bcl-2 expression at the gene and protein levels. ${ }^{*} \mathrm{P}<0.05$ vs. Control; ${ }^{*} \mathrm{P}<0.05$ vs. $12 \mu \mathrm{g} / \mathrm{ml} \mathrm{GA} ;{ }^{\stackrel{P}{P}<0.05}$ vs. $20 \mu \mathrm{g} / \mathrm{ml} \mathrm{GA}$. GA, Gallic acid; Bcl-2, B-cell lymphoma 2; Bax, Bcl-2-associated X protein.

A
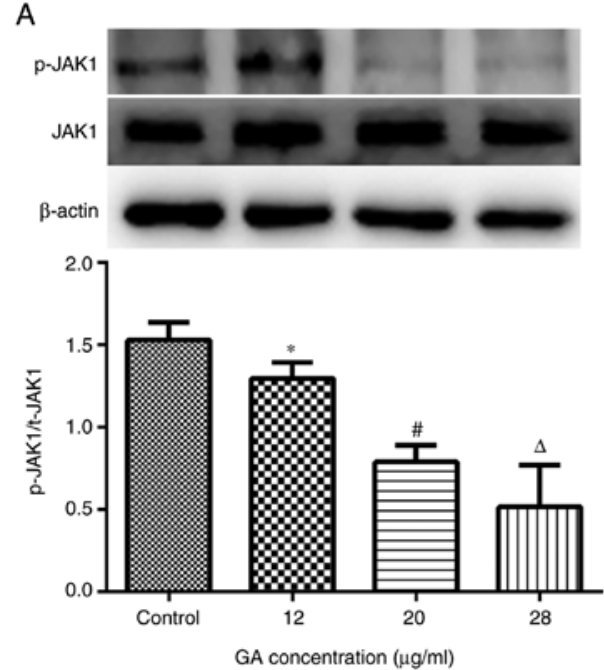

C

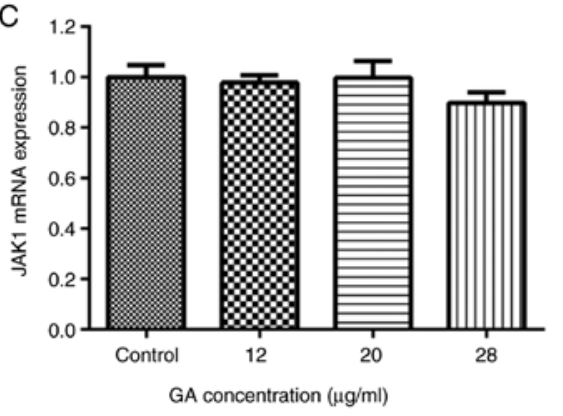

B
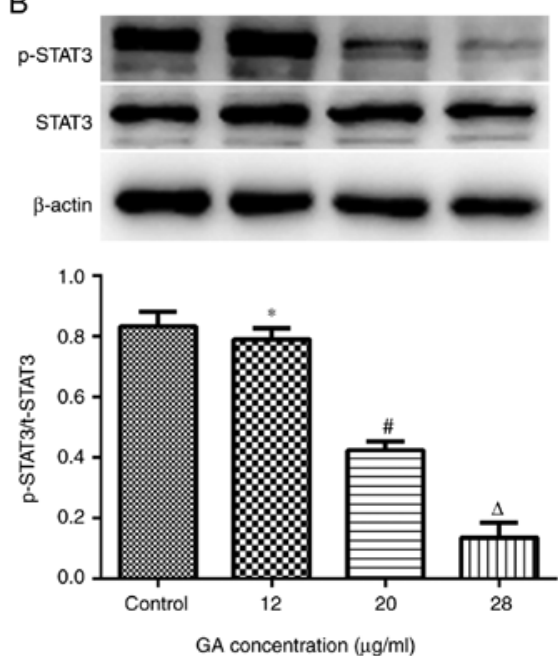

D

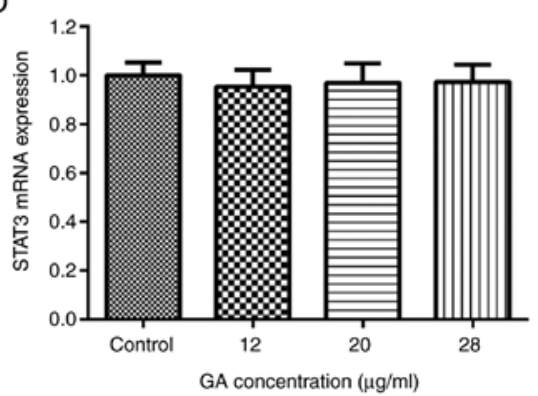

Figure 4. Effects of GA on the expression and phosphorylation of JAK1 and STAT3. GA at $12 \mu \mathrm{g} / \mathrm{ml}$ suppressed the levels of (A) p-JAK1 ${ }^{\text {Y1022 }}$ and (B) p-STAT3 ${ }^{\text {Tyr705 }}$ when compared with control treatment. Greater inhibition of p-JAK $1^{\mathrm{Y} 1022}$ and $\mathrm{p}$-STAT3 ${ }^{\mathrm{Ty} 705}$ levels was observed when cells were treated with 20 or $28 \mu \mathrm{g} / \mathrm{ml}$ GA. Varied doses of GA exhibited little influence on the gene expression of (C) JAK1 and (D) STAT. ${ }^{*} \mathrm{P}<0.05$ vs. Control; ${ }^{\#} \mathrm{P}<0.05$ vs. $12 \mu \mathrm{g} / \mathrm{ml} \mathrm{GA} ;{ }^{\Delta} \mathrm{P}<0.05$ vs. $20 \mu \mathrm{g} / \mathrm{ml}$ GA. GA, Gallic acid; JAK1, Janus kinase 1; STAT3, signal transducer and activator of transcription 3; p-, phosphorylated; t-, total. 

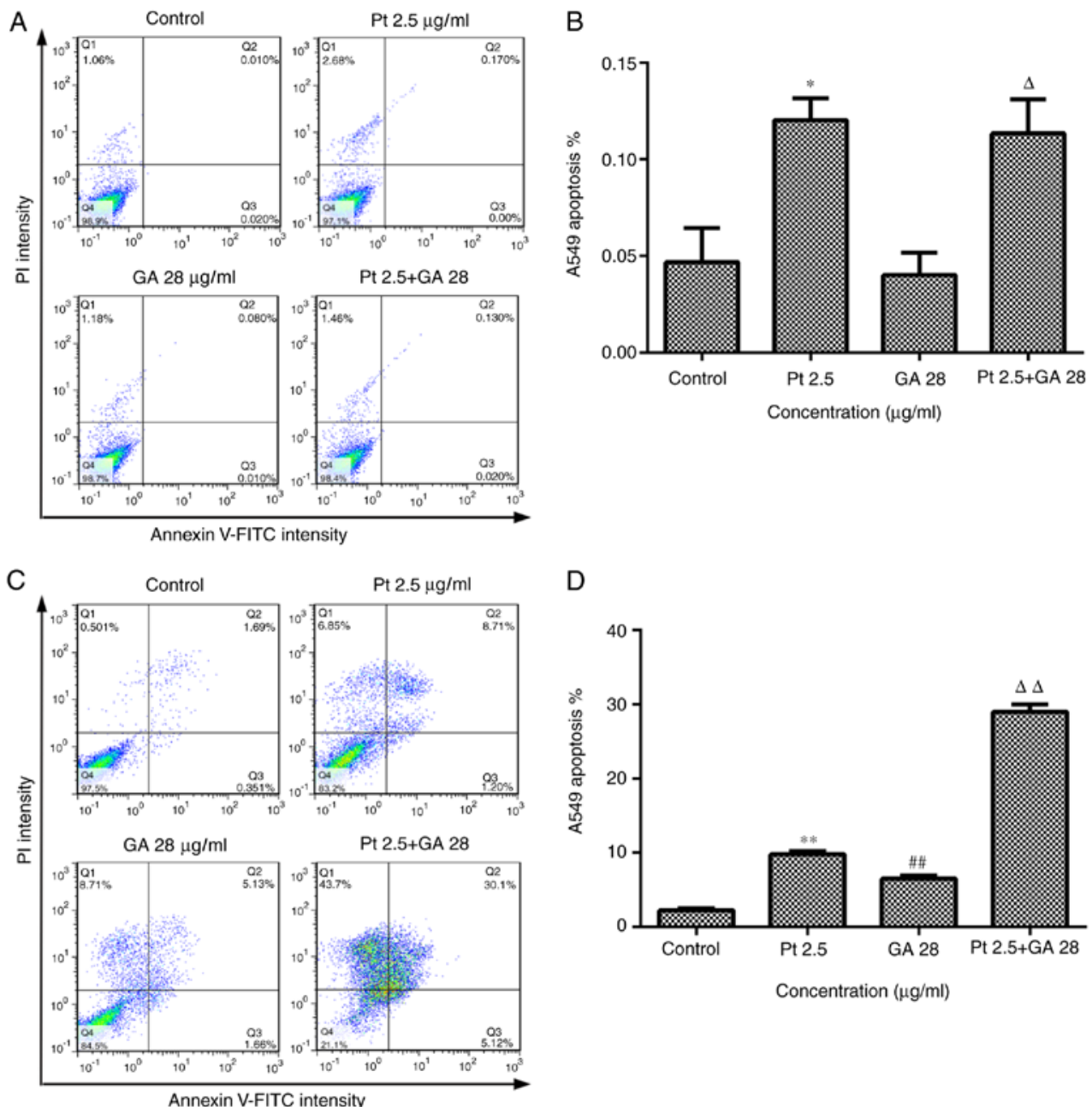

D

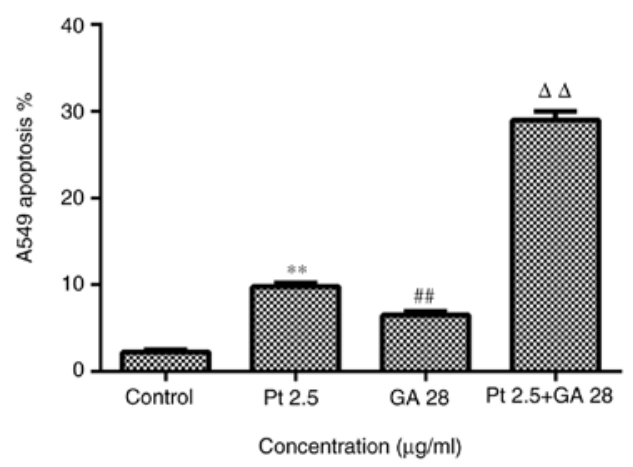

Figure 5. GA enhances the effects of cisplatin on the apoptosis of A549 cells. Cell apoptosis was measured by flow cytometry and the results were expressed as the mean \pm standard deviation of separate experiments. Representative flow cytometry histograms of cell apoptosis are presented in (A) and (C), with the corresponding results of statistical analysis shown in (B) and (D). Cisplatin treatment for (A and B) $6 \mathrm{~h}$ or (C and D) $24 \mathrm{~h}$ increased the apoptosis of A549 cells to varied extents. GA increased the percentage of apoptotic cells at (D) $24 \mathrm{~h}$ but not at (B) $6 \mathrm{~h}$ following incubation. Combined treatment with GA and cisplatin induced a more marked increase in apoptosis than single agent treatment at (D) $24 \mathrm{~h}$ following incubation. ${ }^{*} \mathrm{P}<0.05$ and ${ }^{* * *} \mathrm{P}<0.01 \mathrm{vs}$. Control; ${ }^{\sharp \#} \mathrm{P}<0.01 \mathrm{vs}$. $\mathrm{Pt} 2.5$; ${ }^{\Delta} \mathrm{P}<0.05$ and ${ }^{\Delta \Delta} \mathrm{P}<0.01$ vs. GA 28 . GA, Gallic acid; Pt, cisplatin; PI, propidium iodide; FITC, fluorescein isothiocyanate.

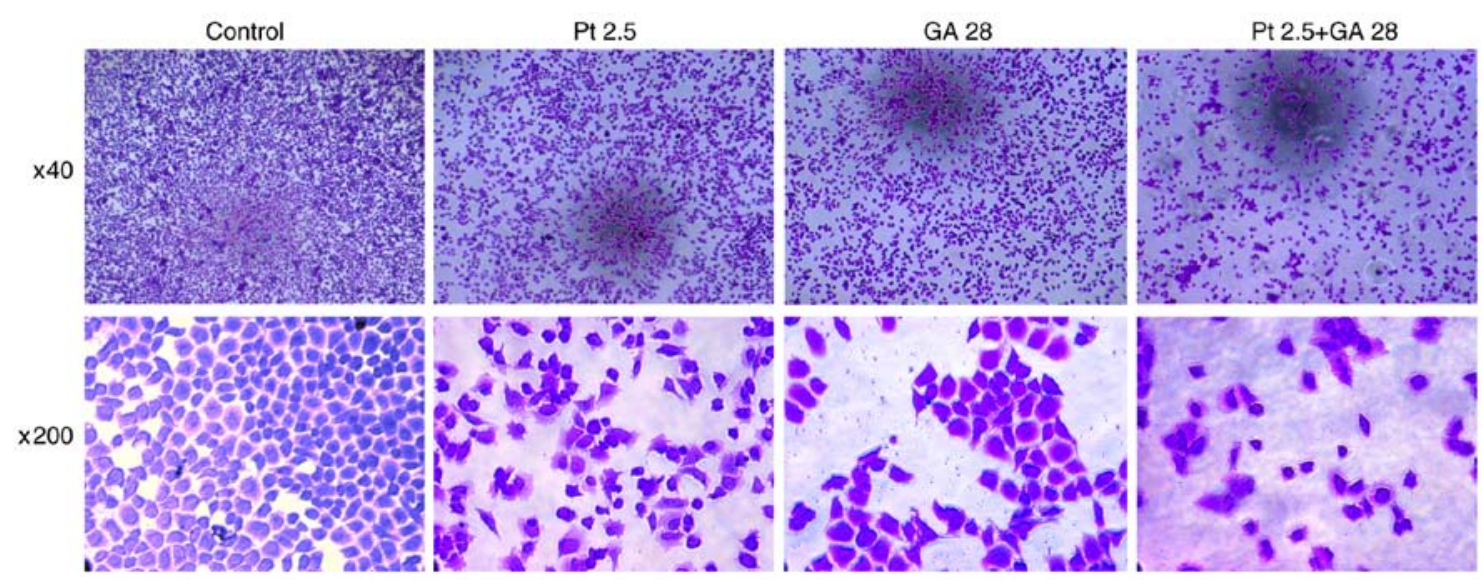

Figure 6. Morphological changes in A549 cells from each group were observed by crystal violet staining. Cellular structure was intact in the control group; however, cell shrinkage, nuclear chromatin condensation and fragmentation were observed when cells were treated with GA, cisplatin, or the two agents combined for $24 \mathrm{~h}$. Combined usage of GA and cisplatin led to greater morphological changes in the A549 cells. Magnification, x40 and x200. GA, Gallic acid; Pt, cisplatin.

GA enhances the effects of cisplatin on the proliferation of A549 cells. To confirm the optimum concentration of cisplatin for subsequent investigations, an MTT assay was performed. As presented in Fig. 1C, treatment with cisplatin $(0-32 \mu \mathrm{g} / \mathrm{ml})$ 
A
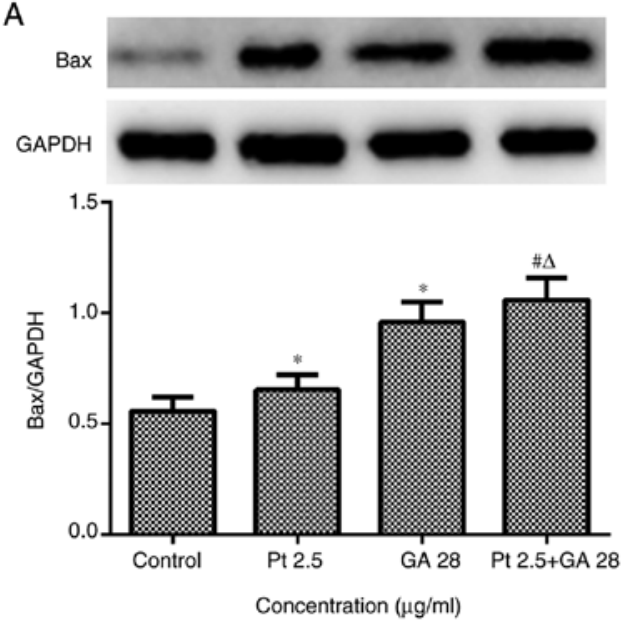

C
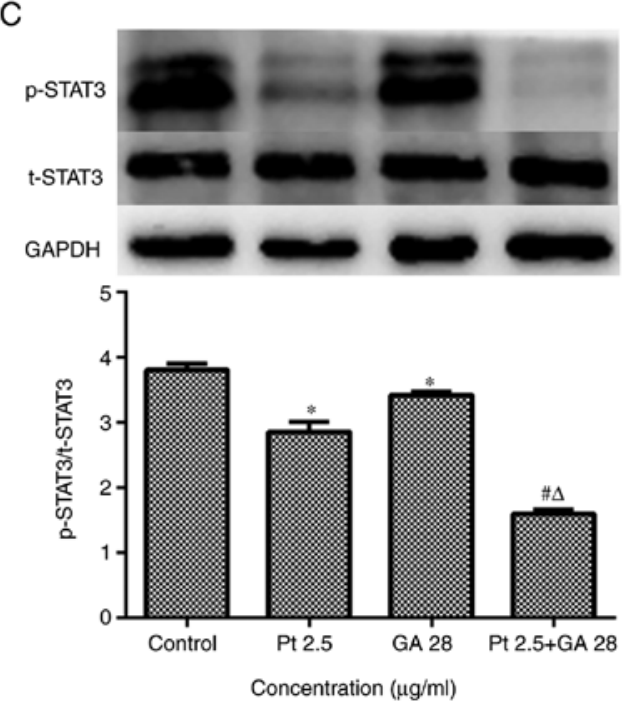

B
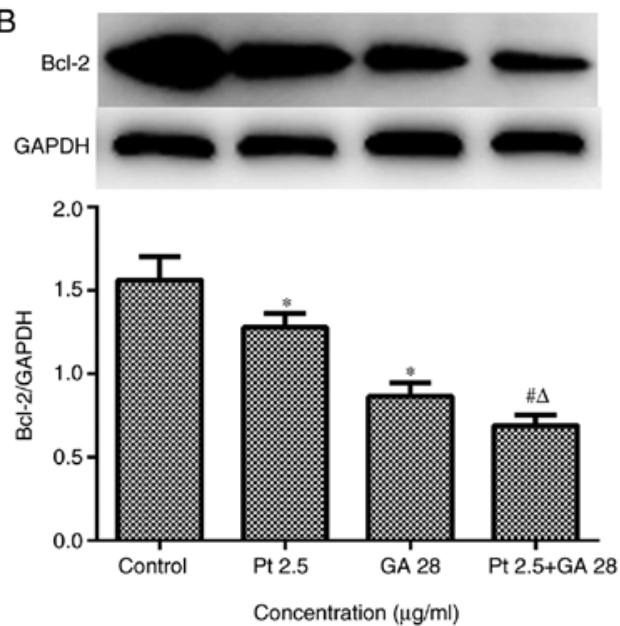

D
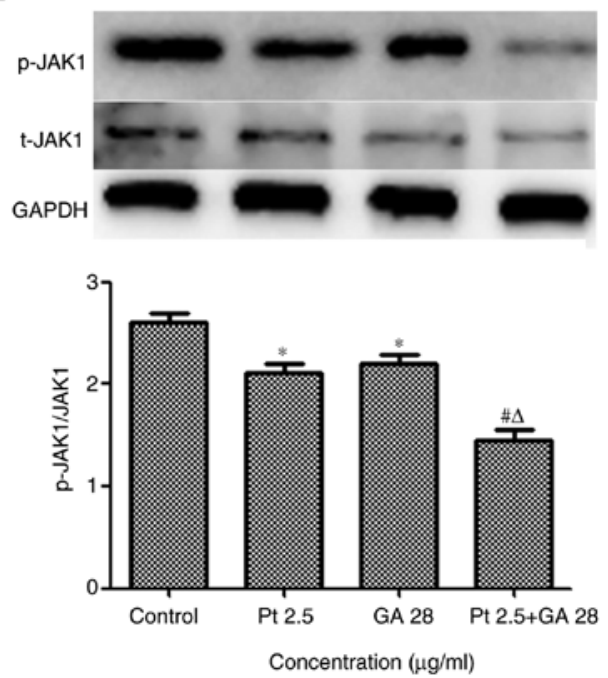

Figure 7. GA enhances the inhibitory effect of cisplatin on the JAK/STAT3 signaling pathway in A549 cells. GA or cisplatin treatment alone (A) increased Bax expression and (B) decreased Bcl-2 expression; combined treatment with the two agents significantly enhanced these effects on the expression of (A) Bax and (B) Bcl-2. The levels of (C) p-STAT3 ${ }^{\mathrm{Ty} 705}$ and (D) p-JAK1 ${ }^{\mathrm{Y} 1022}$ were significantly decreased in cells treated with GA or cisplatin alone, though more marked decreases were observed in the combined treatment group. ${ }^{*} \mathrm{P}<0.05$ vs. Control; ${ }^{\#} \mathrm{P}<0.05$ vs. Pt 2.5; ${ }^{\Delta} \mathrm{P}<0.05$ vs. GA 28 . GA, Gallic acid; Pt, cisplatin; JAK1, Janus kinase 1; STAT3, signal transducer and activator of transcription 3; p-, phosphorylated; t-, total.

for 24 h significantly decreased the viability of A549 cells in a dose-dependent manner $(\mathrm{P}<0.05)$. It was determined that the half-maximal inhibitory concentration of cisplatin was between 2 and $4 \mu \mathrm{g} / \mathrm{ml}$, and thus $2.5 \mu \mathrm{g} / \mathrm{ml}$ cisplatin was adopted for subsequent assays.

To evaluate the effects of combined treatment with GA and cisplatin (Pt 2.5+GA28 group), cells were treated with the established doses of GA and/or cisplatin for 6-48 $\mathrm{h}$ and evaluated by MTT assay. The results demonstrated that GA, cisplatin and their combined treatment decreased cell viability in a time-dependent manner $(\mathrm{P}<0.01)$. Furthermore, cotreatment with GA markedly strengthened the effects of cisplatin at different time points $(\mathrm{P}<0.05$; Fig. 1D).

GA enhances the effects of cisplatin on the apoptosis of A549 cells. To confirm whether GA influenced the stimulatory effects of cisplatin on apoptosis, A549 cells were treated with GA, cisplatin or the two combined for 6 or $24 \mathrm{~h}$, and cell apoptosis was measured by cytometry. The results indicated that cisplatin treatment for 6 or $24 \mathrm{~h}$ increased the apoptosis of A549 cells by varying extents ( $\mathrm{P}<0.05$ vs. Control), while GA significantly increased the percentage of apoptotic cells at $24 \mathrm{~h}$ but not at $6 \mathrm{~h}$ following incubation $(\mathrm{P}<0.05 \mathrm{vs}$. Control at 24 h). Notably, no combined effect was observed when A549 cells were treated with cisplatin and GA for $6 \mathrm{~h}$, which may be due to $28 \mu \mathrm{g} / \mathrm{ml}$ GA not exhibiting any apoptosis-inducing effects on A549 cells following $6 \mathrm{~h}$ of incubation. However, combined treatment with GA and cisplatin induced a significant increase in apoptosis when compared with single treatment with either of the two agents following $24 \mathrm{~h}$ of incubation ( $\mathrm{P}<0.01$ vs. single treatments), which indicated that GA increased the apoptosis-inducing effects of cisplatin on A549 cells (Fig. 5C and D).

GA enhances the effects of cisplatin on the morphological changes of A549 cells. The morphological changes of cells from different groups were observed by crystal violet staining assay (Fig. 6). Cellular structure was intact in the control group, while cells exhibited apparent apoptotic changes such as cell shrinkage, nuclear chromatin condensation and fragmentation 

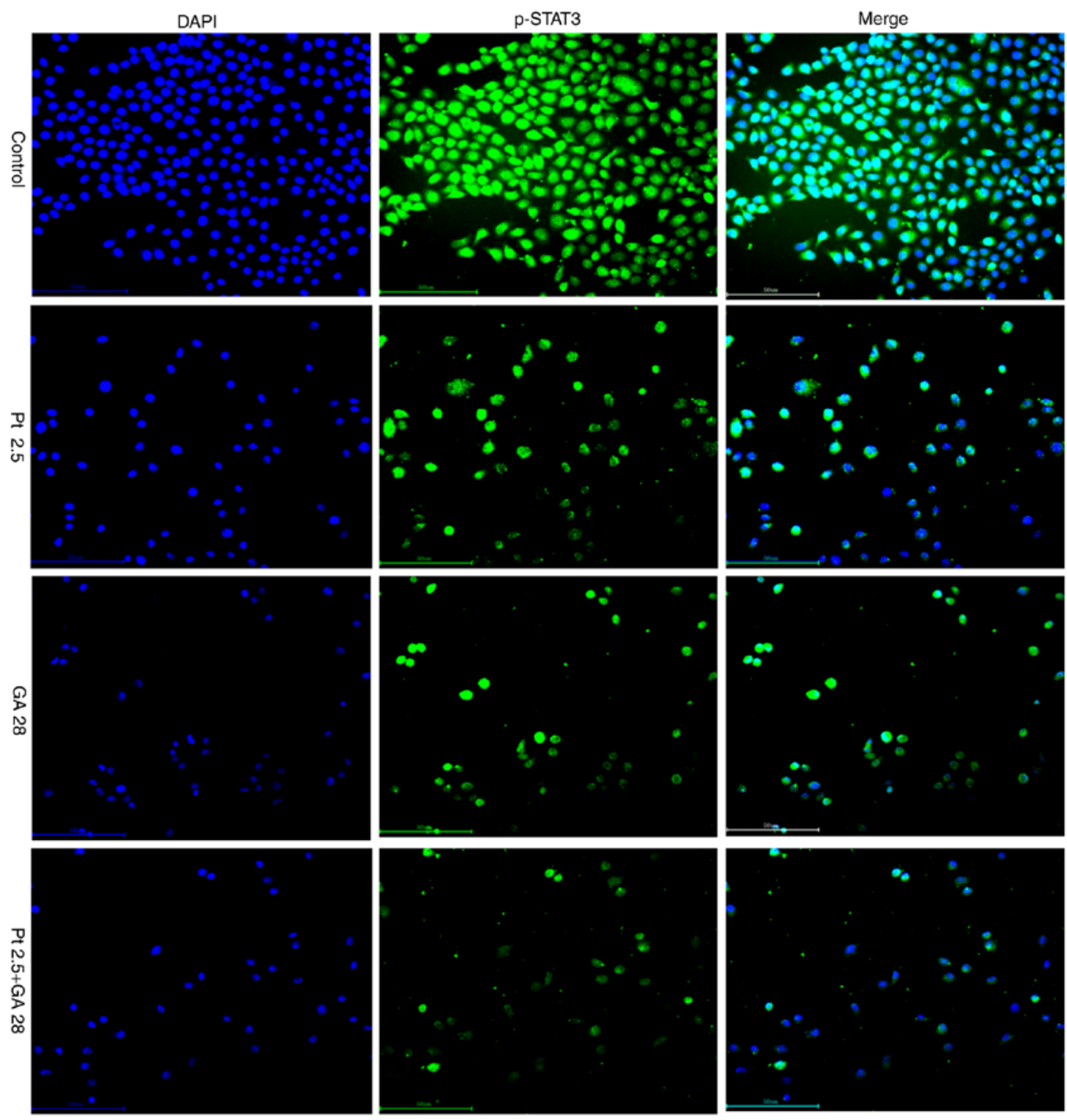

Figure 8. Phosphorylation and translocation of p-STAT3 were detected by immunofluorescent staining. GA, cisplatin or combined treatment with the two agents suppressed the phosphorylation of STAT3 and the translocation of p-STAT3 from the cytoplasm to the nucleus. Combined treatment with GA and cisplatin exhibited markedly stronger suppressive effects on the phosphorylation of STAT3 and translocation of p-STAT3. Scale bars, $50 \mu \mathrm{m}$. GA, Gallic acid; Pt, cisplatin; JAK1, Janus kinase 1; STAT3, signal transducer and activator of transcription 3; p-, phosphorylated.

when treated with GA, cisplatin, or a combination of the two agents for $24 \mathrm{~h}$. Additionally, cells in the experimental groups exhibited an evident decrease in the number of cells; notably, combined treatment with GA and cisplatin together lead to the greatest decrease in cell number. These results revealed that GA or cisplatin treatment alone resulted in morphological changes in A549 cells, though their combination could lead to more evident changes.

GA strengthens the effects of cisplatin on the JAK/STAT3 signaling pathway. To determine whether GA could enhance the effects of cisplatin on the regulation of the JAK/STAT3 signaling pathway, several major molecules associated with apoptosis, anti-apoptosis and proliferation in cells were examined by western blot and immunofluorescent staining assays. The results demonstrated that GA or cisplatin treatment alone increased Bax protein expression and decreased Bcl-2 protein expression $(\mathrm{P}<0.05$ vs. Control); while combined treatment with the two agents significantly enhanced these effects on the expression of $\mathrm{Bax}$ and $\mathrm{Bcl}-2$ ( $\mathrm{P}<0.05$ vs. single treatments; Fig. 7A and B).

The expression of the JAK/STAT3 signaling pathway in cells treated with GA, cisplatin or the two agents combined was also evaluated. The results demonstrated that the levels of p-STAT3 ${ }^{\text {Tyr705 }}$ and p-JAK $1^{\text {Y1022 }}$ were significantly decreased in cells treated with GA or cisplatin alone $(\mathrm{P}<0.05$ vs. Control); however, more marked decreases were observed in the combined treatment group ( $\mathrm{P}<0.05$ vs. single treatments; Fig. $7 \mathrm{C}$ and $\mathrm{D})$. Additionally, the results of immunofluorescent staining revealed that GA, cisplatin or the combination of the two agents suppressed the phosphorylation of STAT3 and the translocation of p-STAT3 from the cytoplasm to the nucleus (Fig. 8), which was consistent with the results of western blotting. Notably, these results also revealed that combined treatment with GA and cisplatin lead to markedly stronger suppression of the phosphorylation of STAT3 and translocation of p-STAT3. 


\section{Discussion}

Lung cancer is one of the most common types of cancers and is characterized by a high mortality rate and resistance to chemo- and/or radiation therapy is easily acquired (16). For the majority of patients with NSCLC, there is difficulty in selecting the optimum therapeutic regimens. Cisplatin-based chemotherapy has achieved considerable success in improving the prognosis and 5-year survival rate of patients compared with non-cisplatin regimens. However, the use of cisplatin is markedly limited by its side-effects, including nephrotoxicity, severe nausea and vomiting (17). There is an urgent requirement to identify novel drugs with little or no side-effects. Recently, plant-derived compounds have attracted increasing levels of public attention for their potential anticancer activities and low toxicity. GA is one such product that exists in various plants and may possess anticancer activity in various cancer cells including those of lung cancers (8). A previous study has reported that GA could enhance the effects of chemotherapeutic agents in lung cancer (7). However, the underlying mechanisms are still not fully understood.

It is well known that apoptosis is a strictly programmed cell death process, which serves a critical role in maintaining the balance between cell survival and death (18). Normally, apoptosis is a critically regulated physiological process; however, abnormal cellular proliferation and accumulation of genetic defects may occur in instances of impaired apoptotic mechanisms, which could further lead to tumorigenesis and resistance to treatment (19). Therefore, abnormal cellular proliferation and evasion of apoptosis are considered to be hallmarks of cancer, and the majority of antitumor drugs exert their effects by inhibiting cellular proliferation and inducing cell apoptosis. In the present study, the anticancer capacity of GA and its auxiliary effects on cisplatin were evaluated, and the results demonstrated that GA and cisplatin had marked effects on decreasing A549 cell viability in dose- and time-dependent manners. Notably, combined treatment with GA significantly enhanced the effects of cisplatin. The present study has also identified that individual GA or cisplatin treatment induced apoptosis in A549 cells, and furthermore, cotreatment with GA enhanced the apoptosis-inducing effects of cisplatin. These results were consistent with previous studies reporting that GA inhibited the growth and induced the apoptosis of hepatic stellate (6), prostate cancer (8) and ovarian cancer cells (9).

Apoptotic pathways are known for their functions in modulating the balance between cell proliferation and apoptosis by regulating the expression of a series of growth factors, cytokines and vasoactive substances (20). An imbalance between cell proliferation and apoptosis is one of the main causes of tumorigenesis (21). Among the key factors involved, the JAK/STAT3 signaling pathway has recently gained increased research focus. Transient activation of the JAK/STAT3 signaling pathway in normal tissue is involved in numerous fundamental biological processes, including cell proliferation and apoptosis, and the development of organs (22). However, persistent activation of the JAK/STAT3 signaling pathway has been observed in several types of cancers including NSCLC (14). Inhibition of the JAK/STAT3 signaling pathway has therefore been recognized as a promising therapeutic strategy for NSCLC. In addition, the JAK/STAT3 pathway may regulate many gene products associated with apoptosis and anti-apoptosis, including Bax and Bcl-2 (23).

Based on this knowledge, the expression levels of JAK1, p-JAK1 $1^{\mathrm{Y} 1022}$, STAT3 and p-STAT3 $3^{\text {Tyr705 }}$ were determined in A549 cells treated with GA, cisplatin or a combination of the two agents in the present study. The results demonstrated that GA and cisplatin had little effect on the expression of total (t)-JAK1 or t-STAT3, while the phosphorylation of JAK1 and STAT3 was suppressed by GA and cisplatin in a dose-dependent manner. Furthermore, it was also identified that GA markedly enhanced the effects of cisplatin on blocking the phosphorylation of JAK1 and STAT3, and that the changes in p-JAK $1^{\mathrm{Y} 1022}$ and $\mathrm{p}-\mathrm{STAT} 3^{\mathrm{Ty}}{ }^{\mathrm{Ty} 705}$ levels were consistent with the changes in cell viability, and contrary to the rate of cell apoptosis. These findings were consistent with previous studies indicating that decreased activation of the JAK/STAT3 signaling pathway could inhibit the growth of ovarian (24) and prostate cancer (10), and renal cell carcinoma (25). To explore the underlying mechanisms by which GA exerted its anticancer effects and auxiliary effects on cisplatin, the major molecules associated with apoptosis, namely Bcl-2 and Bax, were assessed, and the results revealed that the expression of Bcl-2 was downregulated while that of Bax was upregulated in A549 cells treated with GA. Furthermore, GA enhanced the effects of cisplatin on the expression of Bcl-2 and Bax. These results indicated that GA inhibited proliferation and induced apoptosis in A549 cells by regulating apoptotic signaling pathways. However, further studies are still required in order to elucidate how GA affected the downstream JAK/STAT3 signaling pathway and the role of GA.

In conclusion, the present study confirmed, to the best of our knowledge for the first time, that GA suppressed proliferation and induced apoptosis in NSCLC A549 cells in dose- and time-dependent manners, potentially by modulating the JAK1/STAT3 signaling pathway. Notably, the results of the present study suggested that GA exerted an auxiliary effect on cisplatin anticancer activity by blocking the phosphorylation of JAK1 and STAT3, and modulating the expression of downstream apoptotic molecules. However, the further studies are still required to illustrate the role of GA in other potential apoptosis pathway associations. In addition, animal studies and clinical trials will be necessary in order to confirm the anticancer effects of GA on NSCLC.

\section{Acknowledgements}

The authors would like to thank Dr Longfu Zhou, Mr. Yaolei Zhang and Mr. Yaxing Feng (Central Laboratory, The General Hospital of Western Theater Command, Sichuan, China) for their excellent technical support during the present study.

\section{Funding}

The present study was supported by Innovation Project of Sichuan Medical Association (grant no. Q17005) and Scientific Research Project of Sichuan Health and Family Planning Commission (grant no. 18PJ020). 


\section{Availability of data and materials}

All data generated or analyzed during this study are included in this published article.

\section{Authors' contributions}

$\mathrm{ZX}$ and $\mathrm{XF}$ were the major contributors in designing the research. TZ and LM were the major contributors in conducting the experiments, interpreting the data and drafting the manuscript. PW and WL assisted with the MTT and immunofluorescent staining assays. TL and RG were involved in the cell apoptosis assay and RT-qPCR. XD and ZL performed western blotting. All authors have read and approved the final manuscript.

\section{Ethics approval and consent to participate}

Not applicable.

\section{Patient consent for publication}

Not applicable.

\section{Competing interests}

The authors declare that they have no competing interests.

\section{References}

1. Zhu F, Dai C, Fu Y, Loo JF, Xia D, Gao SP, Ma Z and Chen Z: Physalin A exerts antitumor activity in non-small cell lung cancer cell lines by suppressing JAK/STAT3 signaling. Oncotarget 7: 9462-9476, 2016.

2. Kubo H, Suzuki T, Matsushima T, Ishihara H, Uchino K, Suzuki S, Tada S, Yoshimura M and Kondo T: Cyclin-dependent kinase-specific activity predicts the prognosis of stage I and stage II non-small cell lung cancer. Bmc Cancer 14: 755, 2014.

3. Cromie MM and Gao W: Epigallocatechin-3-gallate enhances the therapeutic effects of leptomycin B on human lung cancer a549 cells. Oxid Med Cell Longev 2015: 217304, 2015.

4. Zheng XJ, Yang ZX, Dong YJ, Zhang GY, Sun MF, An XK, Pan LH and Zhang SL: Downregulation of leptin inhibits growth and induces apoptosis of lung cancer cells via the Notch and JAK/STAT3 signaling pathways. Biol Open 5: 794-800, 2016.

5. Carbone DP, Gandara DR, Antonia SJ, Zielinski C and Paz-Ares L: Non-small-cell lung cancer: Role of the immune system and potential for immunotherapy. J Thorac Oncol 10: 974-984, 2015.

6. Chang YJ, Hsu SL, Liu YT, Lin YH, Lin MH, Huang SJ, Ho JA and Wu LC: Gallic acid induces necroptosis via TNF- $\alpha$ signaling pathway in activated hepatic stellate cells. PLoS One 10: e120713, 2015.

7. Wang R, Ma L, Weng D, Yao J, Liu X and Jin F: Gallic acid induces apoptosis and enhances the anticancer effects of cisplatin in human small cell lung cancer H446 cell line via the ROS-dependent mitochondrial apoptotic pathway. Oncol Rep 35: 3075-3083, 2016.

8. Kaur M, Velmurugan B, Rajamanickam S, Agarwal R and Agarwal C: Gallic acid, an active constituent of grape seed extract, exhibits anti-proliferative, pro-apoptotic and antitumorigenic effects against prostate carcinoma xenograft growth in nude mice. Pharm Res 26: 2133-2140, 2009.
9. He Z, Chen AY, Rojanasakul Y, Rankin GO and Chen YC: Gallic acid, a phenolic compound, exerts anti-angiogenic effects via the PTEN/AKT/HIF-1alpha/VEGF signaling pathway in ovarian cancer cells. Oncol Rep 35: 291-297, 2016.

10. Lee JH, Kim C, Baek SH, Ko JH, Lee SG, Yang WM, Um JY, Sethi G and Ahn KS: Capsazepine inhibits JAK/STAT3 signaling, tumor growth, and cell survival in prostate cancer. Oncotarget 8 : 17700-17711, 2017.

11. Wen W, Liang W, Wu J, Kowolik CM, Buettner R, Scuto A, Hsieh MY, Hong H, Brown CE, Forman SJ, et al: Targeting JAK1/STAT3 signaling suppresses tumor progression and metastasis in a peritoneal model of human ovarian cancer. Mol Cancer Ther 13: 3037-3048, 2014.

12. Zhou F, Cheng L, Qiu LX, Wang MY, Li J, Sun MH, Yang YJ, Wang JC, Jin L, Wang YN and Wei QY: Associations of potentially functional variants in $I L-6, J A K S$ and STAT3 with gastric cancer risk in an eastern Chinese population. Oncotarget 7: 28112-28123, 2016.

13. Gritsina G, Xiao F, O'Brien SW, Gabbasov R, Maglaty MA, Xu RH, Thapa RJ, Zhou Y, Nicolas E, Litwin S, et al: Targeted blockade of JAK/STAT3 signaling inhibits ovarian carcinoma growth. Mol Cancer Ther 14: 1035-1047, 2015.

14. Yang CL, Liu YY, Ma YG, Xue YX, Liu DG, Ren Y, Liu XB, $\mathrm{Li}$ Y and Li Z: Curcumin blocks small cell lung cancer cells migration, invasion, angiogenesis, cell cycle and neoplasia through Janus kinase-STAT3 signalling pathway. PLoS One 7: e37960, 2012.

15. Livak KJ and Schmittgen TD: Analysis of relative gene expression data using real-time quantitative PCR and the $2^{-\Delta \Delta C_{\mathrm{T}}}$ method. Methods 25: 402-408, 2001.

16. Lee CY, Sher HF, Chen HW, Liu CC, Chen CH, Lin CS, Yang PC, Tsay HS and Chen JJ: Anticancer effects of tanshinone I in human non-small cell lung cancer. Mol Cancer Ther 7: 3527-3538, 2008.

17. Yu J, Xiao J, Yang Y and Cao B: Oxaliplatin-based doublets versus cisplatin or carboplatin-based doublets in the first-line treatment of advanced nonsmall cell lung cancer. Medicine 94: e1072, 2015.

18. Qian HR, Shi ZQ, Zhu HP, Gu LH, Wang XF and Yang Y: Interplay between apoptosis and autophagy in colorectal cancer. Oncotarget 8: 62759-62768, 2017.

19. Liu G, Pei F, Yang F, Li L, Amin AD, Liu S, Buchan JR and Cho WC: Role of autophagy and apoptosis in non-small-cell lung cancer. Int J Mol Sci 18; pii: E367, 2017.

20. Jin G, Zhao J, Yang YI, Liu K, Jiang Y, Zhang X, Zhang Y, Huang Y, Lu J and Dong Z: JAK/STAT3 signaling pathway mediates endothelial-like differentiation of immature dendritic cells. Oncol Lett 10: 3471-3477, 2015.

21. Fang J, Lau V, Wu PC, Lai CL and Lau J: Imbalance between cell proliferation and programmed cell dealth "apoptosis* in hepatocellular carcinoma. Gastroenterology 108 (4 Suppl 3): A1063, 1995.

22. Wei W, Wu J, Liu L, Tian Y, Buettner R, Hsieh MY, Horne H Dellinger TH, Han ES, Jove R, et al: Synergistic antitumor effect of combined inhibition of EGFR and JAK/STAT3 pathways in human ovarian cancer. Mol Cancer 14: 100, 2015.

23. Tang SN, Fu J, Shankar S and Srivastava RK: EGCG enhances the therapeutic potential of gemcitabine and CP690550 by inhibiting STAT3 signaling pathway in human pancreatic cancer. PLoS One 7: e31067, 2012.

24. Wen W, Wu J, Liu L, Tian Y, Buettner R, Hsieh MY, Horne D, Dellinger TH, Han ES, Jove R, et al: Synergistic anti-tumor effect of combined inhibition of EGFR and JAK/STAT3 pathways in human ovarian cancer. Mol Cancer 14: 100, 2015.

25. Li S, Priceman SJ, Xin H, Zhang W, Deng J, Liu Y, Huang J, Zhu W, Chen M, Hu W, et al: Icaritin inhibits JAK/STAT3 signaling and growth of renal cell carcinoma. PLoS One 8: e81657, 2013. 